CIHM

Microfiche Series (Monographs)

\section{ICMH}

Collection de microfiches (monographies)
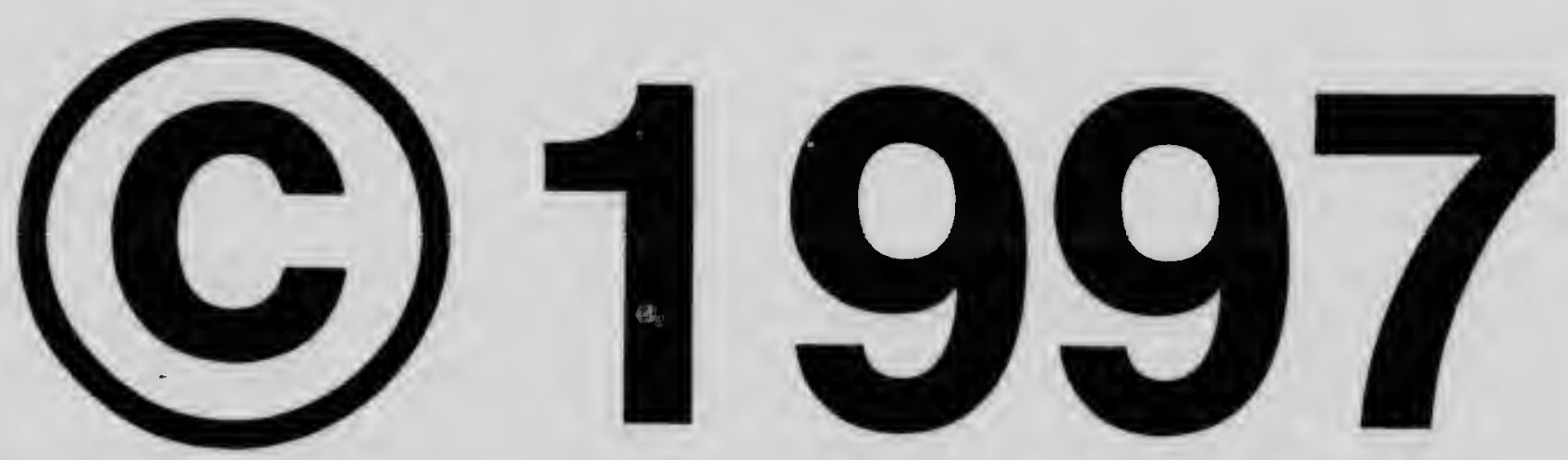


\section{Technical and Bibliographic Notes / Notes techniques et bibliographiques}

The Instltute has attempted to obtaln the best original copy avallable for fllming. Features of this copy which may be blbllographically unique, which may alter any of the Images in the reproduction, or which may slgnificantly change the usual method of fllming are checked below.

\section{Coloured covers / \\ Couverture de couleur}

Covers damaged /

Couverture endommagée

Covers restored and/or laminated/

Couverture restaurée etlou pelliculée

Cover title mlssing / Le ttite de couverture mai ique

Coloured maps / Cartes géographiques en couleur

Coloured ink (i.e. other than blue or black) /

Encre de couleur (i.e. autre que bleue ou noire)

Coloured plates and/or illustrations /

Planches etou illustrations en couleur

Bound with other material /

Relié avec d'autres documents

Only edition available /

Seule éditlon disponible

Tight binding may cause shadows or distortion along interior margin / La reliure serrée peut causer de l'ombre ou de la distorsion le long de la marge intérieure.

Blank leaves added during restorations may appear within the text. Whenever possible, these have been omitted from filming / II se peut que certaines pages blanches ajoutées lors d'une restauration apparaissent dans le texte, mais, lorsque cela était possible, ces pages n'ont pas été filmées.

Additional comments /

Commentaires supplémentaires:
L'Instltut a microfllmé le mellieur exemplaire qu'll lul a été possible de se procurer. Les détalls de cet exemplalre qul sont peut-etre unlques du polnt de vue blbllographlque, qul peuvent modifler une Image reprodulte, ou qul peuvent exiger une modification dans la méthode normale de filmage sont indiqués cl-dessous.

\section{Coloured pages / Pages de couleur}

\section{Pages damaged / Pages endommagées}

Pages restored and/or laminated /

Pages restaurées et/ou pelliculées

Pages discoloured, stalned or foxed /

Pages décolorées, tachetées ou plquées

\section{Pages detached / Pages détachées}

\section{Showthrough / Transparence}

Quality of print varies /

Qualité Inégale de l'impression

Includes supplementary material /

Comprend du matériel supplémentaire

Pages wholly or partially obscured ty errata slips, tissues, etc., have been refilmed to ensure the best possible image / Les pages totalement ou partiellement obscurcies par un feuillet d'errata, une pelure, etc., ont été filmées à nouveau de façon à obtenir la meilleure image possible.

Opposing pages with varying colouration or discolourations are filmed twice to ensure the best possible image / Les pages s'opposant ayant des colorations variables ou des décolorations sont filmées deux fois afin d'obtenir la meilleure image possible.

This item is flimed at the reduction retio checked below I

Ce document eat fitms au taux de roduction indtiqus ct-deseowe.

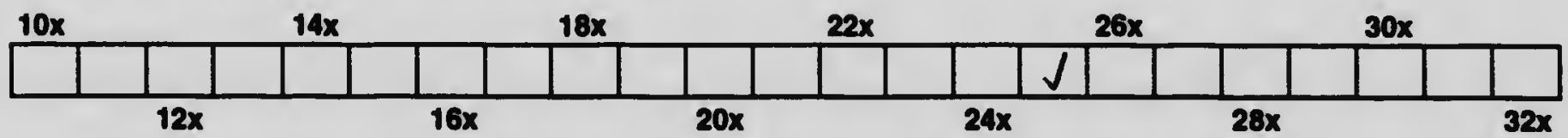


The copy flimed hare bas been reproduced thanks to the genarodity of:

\section{Librery \\ Apriculuure Ceneda}

The images appearing here are the beet quallty poselble conaldering the condition and loglbility of the original copy and In keoplng with the filming contract epocifications.

Original copies in printed paper covere are filmad baginning with the fromt cover and ending on the last page with a printed or Illustrated Impresslon, or the back cover when approprlate. All other original coples are filmed beginning on the firat page with a printed or lliuetratad Impreasion, and andling on the last page with a printed or lliustrated Impreselon.

The last recorded frame on each microfiche shall contaln the aymbol $\rightarrow$ Imeaning "CON. TINUED"), or the symbol $\nabla$ (meaning "END"). whlchover applice.

Mape, plates, charts, etc., may be filmed at differeme reduction retlos. Those too large to be entirely Included In one exposure are fllmed boginning In the uppor loft hand cornor, loft to right and top to bottom, es many fromes as required. The following dlagrems Illustrate the mothod:
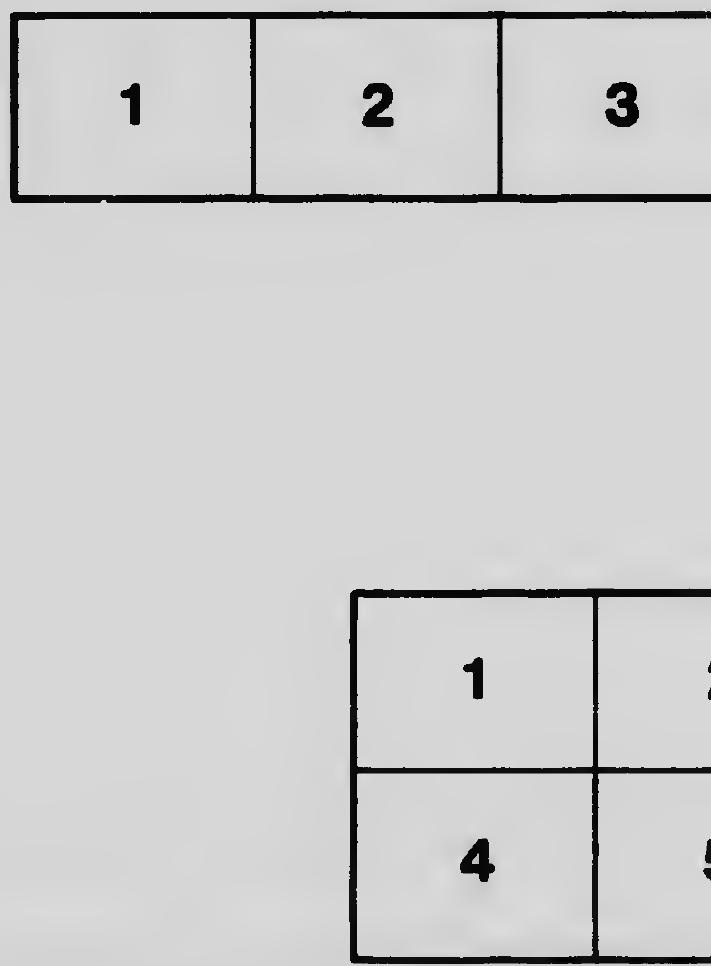
L'exempieire films fut reprodult orsce 1 is osnóroeites do:

\section{Bibliothdque \\ Agriculture Canada}

Les imoges sulventes ont cite reprodultes ovec is plus grand soin, compte tenu do ie condition ot do is nottots de i"oxemplaire filims, ot on conformits ovec les conditions du controt de flimoge.

Les exomploires originoux dont lo couverture on papier eat imprimbe sont filmbs en commencant par is promier piot ot en terminont soit por is derniture page qui comporte une empreinte d'impression ou d'illustration, solt par lo second. plat, solon lo cas. Tous ics outres exempiaires originaux sont filmse en commençent per is premilure pege qui comporte une empreinte d'imprecelon ou d'lilustration of on torminont por ie dernibre page qui comporte une telle empreinte.

Un des eymboices suivents epparattre sur ia dernibre imege de cheque microficho, solon lo cas: io aymboio $\rightarrow$ signifio "A SUIVRE", io symbolo $\nabla$ signifio "FiN".

Les cartes, pienches, tabiesux, otc., pouvent stre flimbs d des toux de riduction diffirents.

Loreque is document eat trop orand pour utre reproduit on un seul clichs. II est films d portir do l'onglo supdriour gouche. de gouche d droite. ot de hout on bes, en pronent io nombre d'imeges nicesesaire. Les diagremmes suivents illustrent la mithodo.

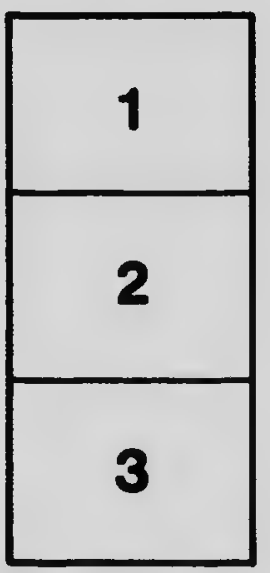

\begin{tabular}{|l|l|}
\hline 2 & 3 \\
\hline 5 & 6 \\
\hline
\end{tabular}


Miciocery RLOCUTION TEST CHARt

(ANSI and ISO TEST CHART No. 2)
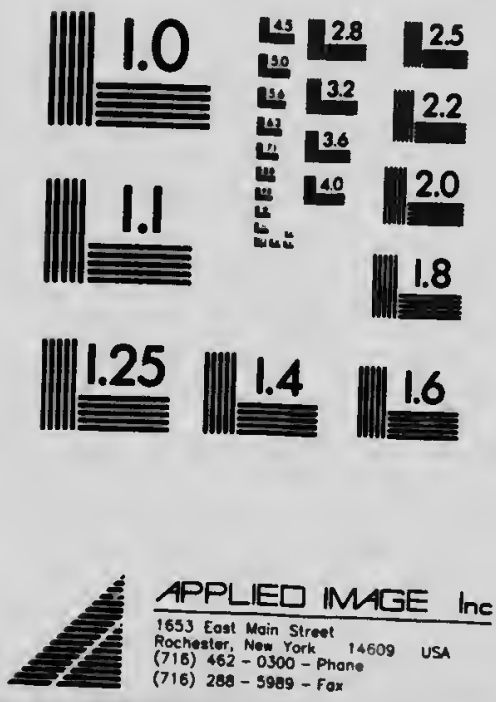


\section{DUNINION OF CANADA \\ DEPART.MENT OF AGRICUITURE \\ ENTOMOLOGICAL BRANCH \\ C. (iohdon Hewist, Duminion fintomglogimt.}

\section{THE CONTROL OF CUTWORMS}

IN THE

\section{PRAIRIE PROVINCES}

By

E. H. STRICKLAND, M.Sc.

Field Officer.

CIRCULAR No. 6

I utlist $\epsilon d$ by direction of Hon. MARTIN BURRELL, Minister of Agriculture, Ottawa, Ont.

OTTAWA

GOVERNMENT PRINTING BUREAU

$83386-1$ 1916 
NOTE.

Ail inquirips reiating to insect pests, and packagew (up to 11 ounces in weight) eontaining specimens may be maiied "Free" if acidressed to the Dominion Entomologist, Department of Agriculture, Ottawa.

In ail cases where it is possible, iiving specimens of the insets shouid be sent enciosed in a strnng wooden or tin box to prevent damage in transit. Llving Insects shouid be suppiied with a liberai quantity of their food plant, and in all cases the $y$ shouid be carcfully packed.

The name and address of the sunder should be written on the outside of the package, and a letter giving as full details as possible should in all cases accompany the insects sent in for report.

Farmers in the prairie provinces may communicate with either of the foilowing Field Officera: Mr. E. H. Strickland, Dominion Entomological Laboratory, Lethbridge, Alberta, or Mr. Norman Criddle, Dominion Entousulogicai Laboratory. Treesbank, Manitoba, regarding insect injuries, particularly in eases of emergency. Letters and packages to these officers must bear postage and cannot be mailed free. 
Otrawa, Deersuleer 1, 1915.

To the Honourable

The Minister of Agriculture. Ottawn.

Sin, - I have the honour to subnit for your approval Entomologient Circular No. 6, entitled "The Control of Cutworms in the Prairie Provinees," which has been written by Mr. E. H. Strickland, Field Officer in charge of tho Entonological Laboratory at Lethbrilge, Alberta.

Owing to the serious outbreak of Cutworns in southern Allertn in 1912. when unwards of 35,000 aeres of grain were lestroyed in one listrict, it wns deciled to investigate the speeies of Cutworns responsible for the dumange and the most satisfactory methols of control under western conlitions. Mr. Strickland has been stationed at our Entomological Laboratory at Lethbridge, Alta., since 1913 and during the past three seasons he has mate a careful study: of alt the commoner species of Cutworms and has carricrl out extensive experiInents on their control. Our thanks arc due to Mr. W. H. Fairfield, Superintendent of the Dominion Experimental Station at Lethbridge, where our Lahoratory is situated, for his co-opcration and assistance at all times.

In order to make the results of Mr. Strickland's work immediately ar:il convenicntly accessible to the farmers of the prairie provinces it is considered preferable to publish a brief circular setting forth the habits and the main results of the investigntions on control measures. It has been found thint under the drier conditions met with in certain of the prairie districts, particularly in southern Alberta, modifications in the usunl poisoned baits are necessary.

It is most important that farmers and market garleners should keep their 'ps under closer supervision than is usually the custom, with a view to detecting , ns of Cutworms or other insect injury in the carly stages. Such constan. gilance would frequently result in the prevention of serious financial losses by idering possible the adoption of control measures before the damage hail ussumed extensive proportions.

I have the honour to be, Sir,

Your obedient servant,

C. GORDON HEWITT, Dominion Entomologist. 


\title{
THE CONTROL OF CUTWORMS IN THE PRAIRIE PROVINCES.
}

\author{
By E. H. Strickund, Fleld Officer for Albertn, Lethbridge, Alberta.
}

Cutworm: constltute the most destructlve Insects with whlch the farmers In the Pralrie Provlnces have to contend. Two species are apeclally Important, namely, The Red-backed Cutworm ( Euxou ochrogaster) and the Pale Western Cutworm (Porosagrotis orthogonia). A thlrd species known as the Army Cutworm (Chor izagrostis auxiliaris) occurs less frequently, though in : - rreater numbers locally. On account of lts spucialised hablts lt calls for different treatment from that employed for other cutworms and it is not Included in thls circular.

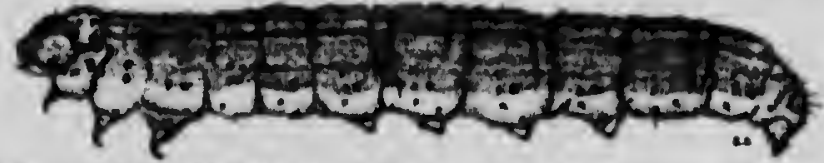

Fo. 1.-Full grown Red-backed Cutworm; twleo natural sise. (Original).

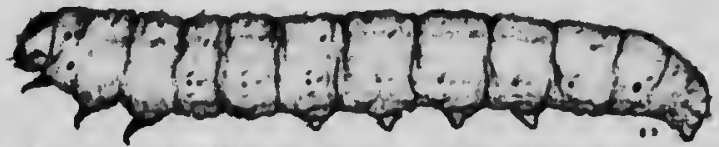

Fto. 2. - Full grown Pale Wewtern Cutworm; twleo natural alae. (Original).

CENERAL LIFL-HLTORY OF CUTWORMB.

The eggs from which cutworms hatch are lald by a moth, or, as it is commonly called, a "miller," in August and Scptember. Th $2 s 0$ of the prairie inhabiting species have been found in or on the soil. Most of them remain unhatched through the winter though a few hatch before the ground freezes up, and the young caterpillars begin to feed in the fall. These remain inactive underground through the winter and resume feeding as soon as the frost is out of the soil in the spring. The majority of eggs, however, lo not hatch until the middle of April, by which date much of the spring sown crop is above ground. From

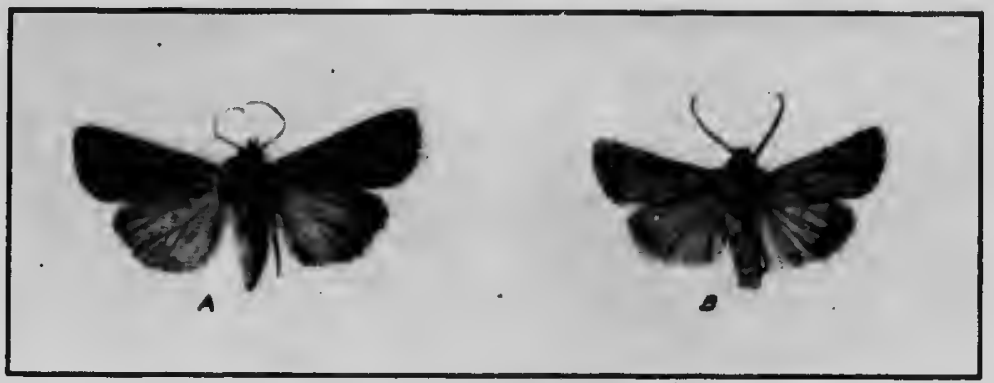

Fic. 3.-Cutworm moths: $a$, Red-backed; $b$, Pale Western; natural sire. (Alter Gibson).

then on to the middle of June the cutworms feed extensively upon all classes of crops, and many weeds. By the latter date, in normal seasons, all are mature and have formed small oval cells in the earth within which they remain for a period $r$ anging from a few days to about a month before turning to a brown pupa from which, at the end of another month the moth hatches. These moths fi y almost exclusively at night time and must not be confused with the small moths which occasionally swarm on the prairie by day. 
HABIT, or cutwokMs.

Both of the injurious true Cutworms of the Prairie Provinees remain below ground during the diny, coming near of to the surface at night in order to search for food. They rareiy feed while on the surface, but burrow into the soil near a piant to bite through the ntem below ground. Bometimes they continue to feed on the piant and draw it down for a considerabie distanee into the goil. When the soli is very ciry, however, they more frequentiy simpiy bite through the stem leiow ground and pass on to tie next piant, whlch is simliarly destroyed. This habit accounts inrgeiy for the fact that cutworms dio more dannk. In dry than In wet years. In wet soil tho cutworms are abie to move less freely lielow ground anil come in tho surface more extensiveiy. At such times they feed more freely above gruu:al. Slnce, however, the prairle is very dry as $n$ ruie during the cutworm period, they feed upon the surface to a very nuch less extent than they do in regions where the rainfnll is grester. For this reason

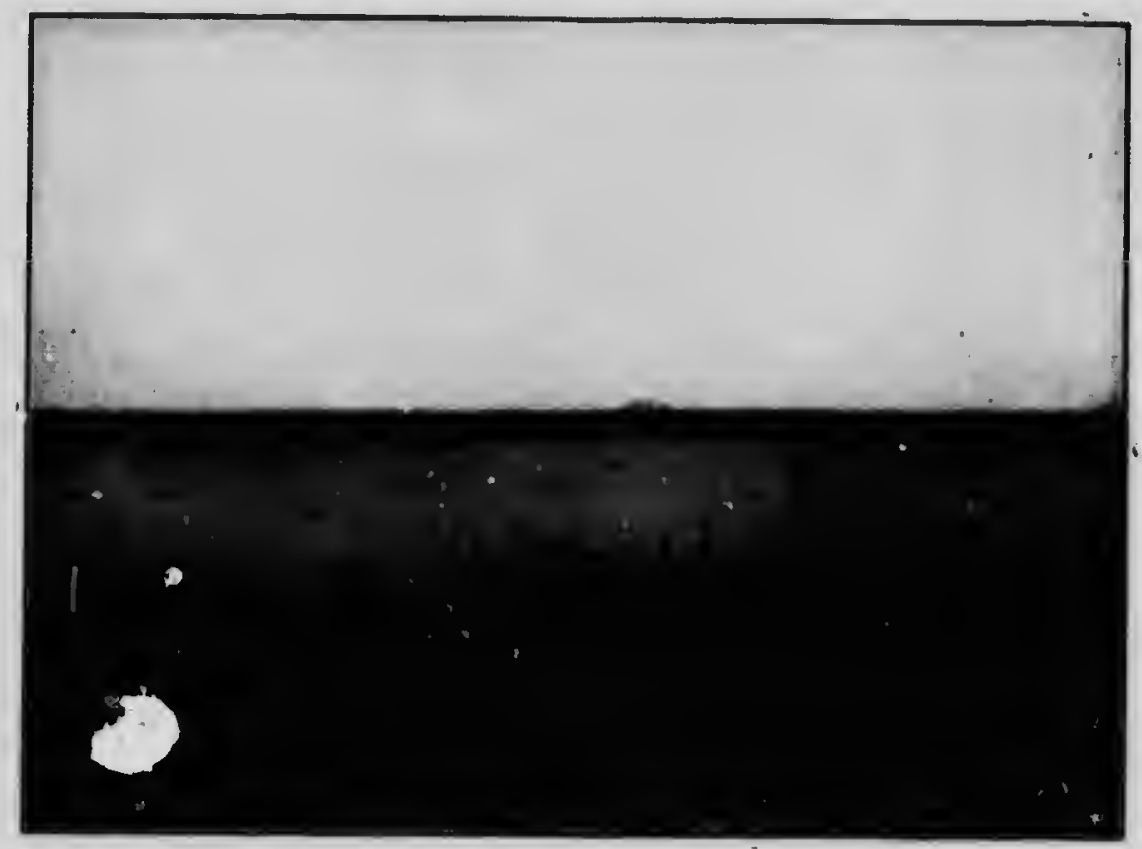

Fo, 4. - Fall wheat, after summer fallow, deatroyed by Pale Western Cutworn, showing clisacterintio damage to a alightly elevated spot. (Original).

control measures practical elsewhere are largely a failure $;$ 'hen applied to prairie conditions, and the modifications given below are necessary for successful control with poisoned baits.

Cutworms avoid moist or hard stil when possible and are found in the largest numbers in the driest and most dusty or sandy parts of a field, where they can move freely "ust below the surface. Fnr this reason they are usually most numerous early the season upon the higher parts of a field where the soil dries out more sapidly in the spring. Later, they become much inore scattered and may be present in $\mathrm{sr}$ all numbers throughout the entire field.

None of the usual p.airie crops is immune from cutworm attack, for they feed freely upon grain, flax, roots and alfalfa, as well as upon all kinds of vegetable crops. The presence of eutworms in a field is not due to the crop that is being grown, but to the treatment of the field during the previous year. 
HABtT or THE Motus.

The moths fly from the middle of July to the middle of September. Throughout August and tlli about the 20th of Reptember thry are laylns the er from which will hateh the next seavon's eutworms. The locations seleoted for eceslaylng aro almont excluslvely weedy summer fallowe, partloularly thnee with a rough surface. The mothe hlde under the elods by day, but usualiy will not lay their erg in, or on, the soll at a dintance from green growth; so that even a rough fallow field on whloh there lo no green mrowth whatever during August and september in fairiy safe from eutworm attarks in the following year. Clean stubble land is rarely chosen by the moths for egg-layins and when eutworms appear in such fields the following year they have usually migrated In from neighbouring feld where weeds were allowed to grow. A fidd of which tho surface is not broken and therefore does not offer sheiter for moths, even

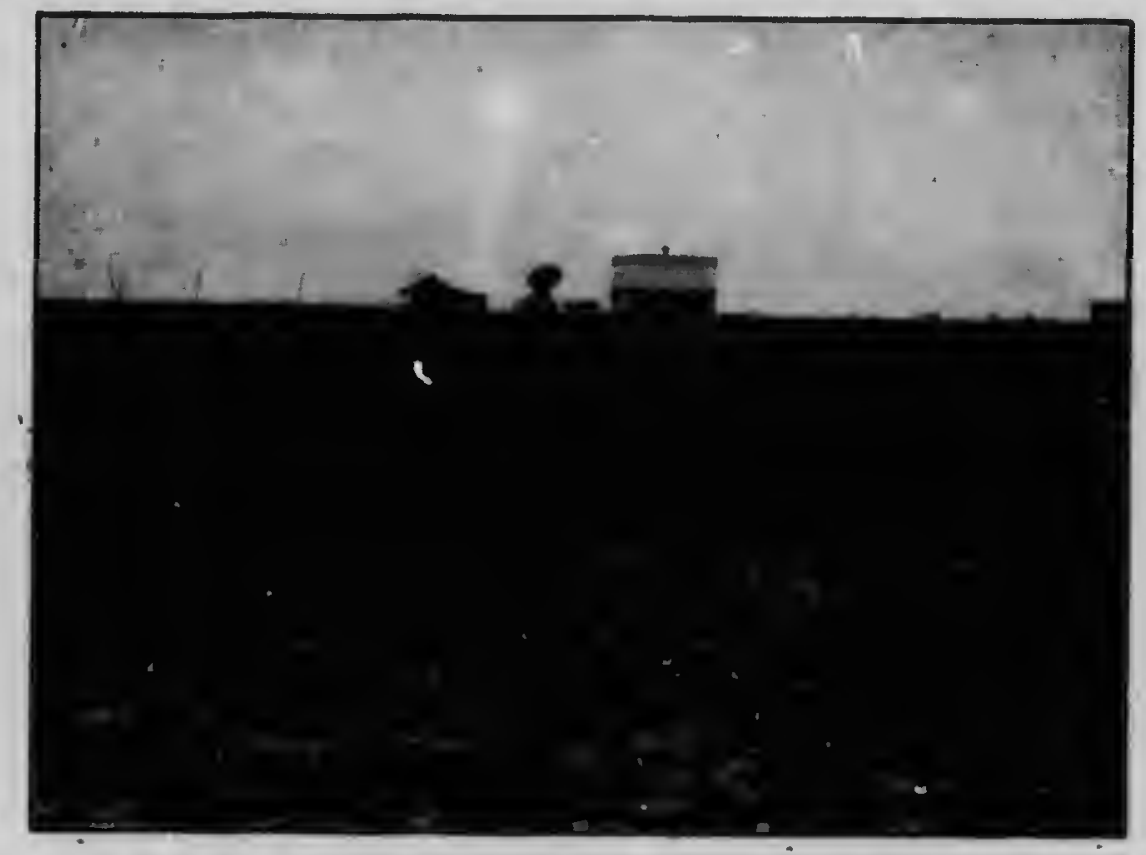

Fio. 5.-Flax foliowine wmmer faliow dentroyed by Red-backed Cutworm, showing mbequent crowth of weeds which attract moths for ear-layinu. (Original).

though it be very weedy, is in leps danger than is a rough summer fallow upon which a small growth of weris : t volunteer grain has been allowed to remain during the egg-laying perind.

\section{CONTROL MEASURES.}

Attention to fallow land. - Crops following summer fallow are always most liablu to eutworm attacks. The reasons for this are given above, and a consideration of them will at once suggest measures which will render fallow land less attractive to cutworm moths for egg-laying.

Summer fallow must be kept absolutely free from all green growth between August 1st and September 20 th and should be worked as finely as is consistent with good cultural practices. 
Date of soving fail wheat. - Since fail wheat in attractive to the moths for exp-laylne it should not be nown earlier than the second week In Beptember in order that it will not be above sround before the moths dilsappear.

Fall ploughing. - Land whlch ian been allowed to grow up to werds, and weedy stubbie land, whouid ise pioughe! as deepiy an ponsibie in the fail, for on weh land numerous exs are deposited, and if well ploughed theme eres are buried so deeply that many of the cutworma hatchlng from them die from atarvatlon before they reach the surface. This nietiod of dentruction is not, however, very certaln, though if the fieid be harrowed or packed aftur pioughing its efficacy is incressed.

Poisoniso wirn saits. - For field sontrol under pralrie concitions, it is seldom practical to spread poisoned bi 6 over large areas on account of the expense of such an operatlon. Poisoning is, however, niwayn a vaiualie and profitable methol of controlling cutworms in market gardens and when properly empioyed can be used successfuily in grain ficids.

It has been stated that cutworms are moat destructive to crops foliov: summer faliow, and that it is from spots, which for some renson, such ar $i i_{1}, \mathrm{r}$ being higher than the grouni-ievel of the field, are drier than tive reis at b general infection spreads. Such piaces should be watched from time to :... a the spring. If during the latter part of April or in May any slgns of cutworm dainage are seen 0 . them they should be treated Immediateiy with the balt describeri below, jis i.jer that the young caterpillar may be killed before they have become scattered throughout the whole field. In this way the damage to many acres may be considerabiy lessened by treating a comparatively smail area. Fa:mers who delay treatment until these centres of infestation are neariy or quite atripped may find that the infestation has becume too general to warrant the expense of polsoning.

The poisoned bail.-As a resuit of numcrous experiments that we have carried out it has been found that the most reilable poisoned bait mixture for pralrie conditions is the following:-

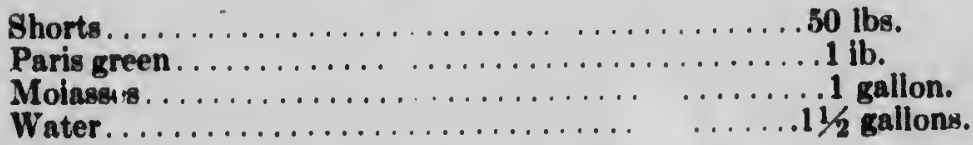

Shorts are preferable to bran for dry farmini: enditıons, because no bait can be kept moist when applied to the soil, anci cut worms will eat dry shorts when they refuse dry bran. In damp loralities and. sensons when the soil is moist the shorts can be repiaced with ar ty $3 a$ weight of bran in which case three gallons of water should be used instes $: 11 / 2$ galic:s. In all cases, however, shorts give somewhat better results than bran. Brude beet molasses* give the best resuits. It is suggested that arrangements be made with a storekeeper at each town in infested districts to keep a barrel ot this extremely cheap and valuable materiai on hand.

Preparation.-Thoroughly mix the shorts and Paris green while dry. Care must be taken not to ailow more of the Paris green dust to br. breathed than is absolutely unavoidable, when making this mixture, for it is a violent poison. A handkerchief tied over the mouth will lessen any danger from this source.

Stir the molasses into the water and add the solution slowly to the shorts and Paris green, thoroughly mixing with the hands all the time to prevent lumps forming.

Application.-Apply to infested areas and for a few feet beyond at the rate of 50 pounds of shorts per acre, preferably in the late afternoon.

This material can be obtained Irom beet sugar nollls such as the Raymond Sugar Mills, Raymond, Alberta. 
When the soil is very dry it is essential that the ground be lightly harrowed after the bait has been applied, for, as pointed out earlier, the cutworms feed almost exclusively below ground under these conditions, and a surface application of poisoned bait is nearly all wasted.

Harrowing is not necessary when the soil is moist.

Resowing fields after cutworm devastation.-No definite date can be given as to when it is safe to re-sow a field which has been destroyed by cutworms on account of the annual variations in season. During the past three years the date has varied from June 18th to June 28th, but farmers who desire to re-sow fields and wish for advice upon the subject are advised to send specimens of the average sized cutworms to either of the Dominion Entomological Laboratories at Treesbank, Manitoba, or at Lethbridge, Alberta, in order that they may receive information as to the approximate date when re-sowing will be safe in their district.

\section{CONTROL MEAsURES NOT SUITABLE TO OUR PRAIRIE conditions.}

Farmers are sometimes confused by the variety of methods recommended for the control of cutworms. While a ceertain measure may be effectual in one region it may fail completely in another. In the course of our investigations we experimentel with all kinds of methods of control, including baits, and in order that farmers may avoid unnecessary expense and disappointment we will indicate a number of control measures which are sometimes advocated but which we cannot recommend.

Light traps in the field.-A method of control, which has been occasionally recommended for cutworms consists of placing liglit traps in the field in order to catch the moths. Experiments with various light traps carried out by Mr. Norman Criddle in Manitoba and by the writer in Alberta have shown that such lanterns attract the moths of destructive cutworms in extremely sniall numbers and are absolutely valueless under prairie conditions as a means of control.

Lime and Salt.-The applications of these substances to fields for the destruction of cutworms has not been found to have any beneficial results.

Fruit juice added to baits. - Though this is apparently a valuable material when added to grasshopper baits, it has not proved to be of appreciable value when utilized for the control of prairie inhabiting cutworms.

Sugar and Salt added to baits.-Both of these substances are inferior to molasses as attractive agents and their use cannot be recommended in poisoned bait for application to dry soil when molasses are available.

Stubble burning in the Fall. - Cutworm eggs are rarely found in clean stubble land, whereas when a cropped field is so weedy that cutworm moths are attracted for egg-laying it is difficult to obtain a good burn. It is not advisable to burn over clean stubble land in the fall if the stubble will be of value for catching snow during the winter. 


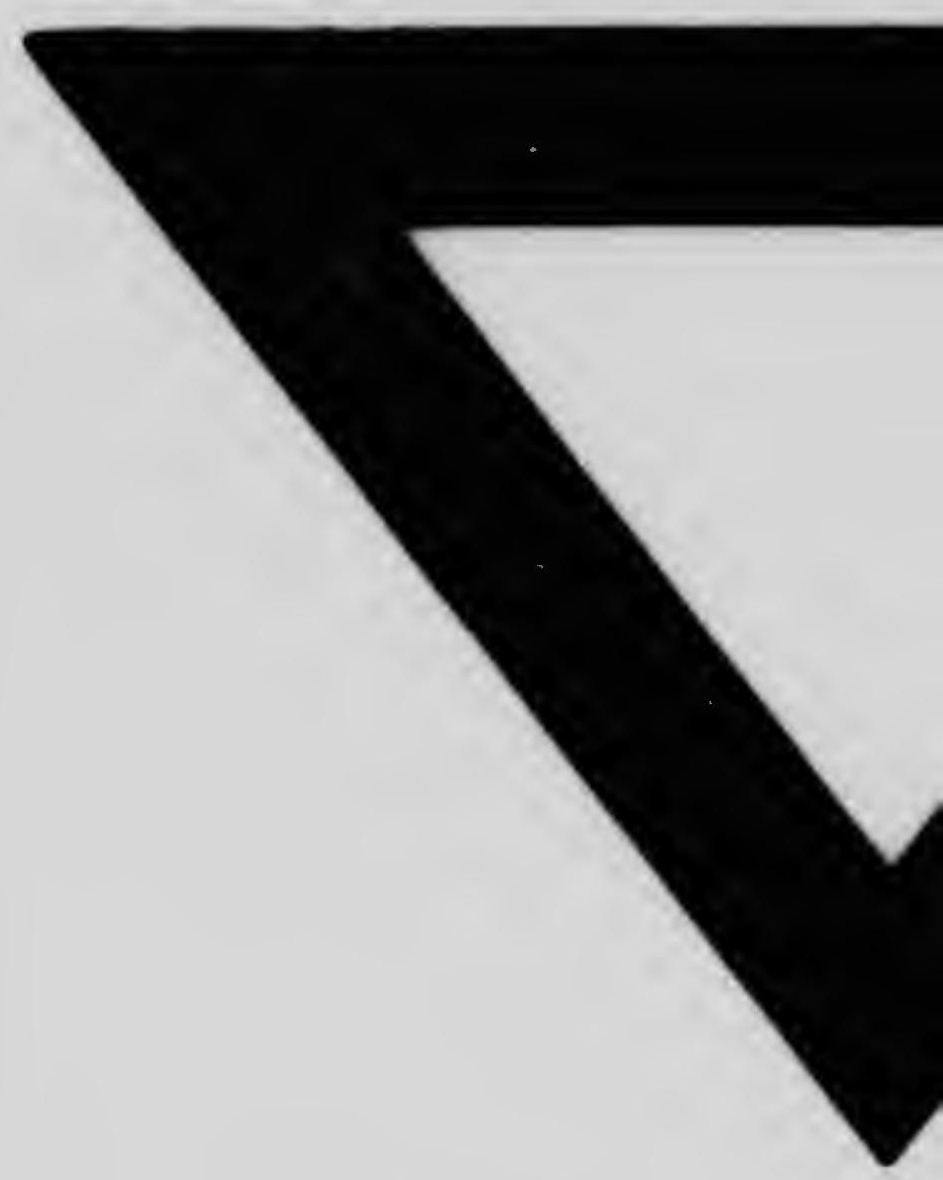




$$
7
$$

